\title{
Microfracturas en paneles solares y sus implicaciones en la producción de energía
}

\author{
Microcracking on PV modules and their implication on energy generation
}

\author{
Héctor D. Molina-Ruiz ${ }^{a}$, Venkata K.K. Tangirala ${ }^{b}$ Lizeth Martínez Ayala ${ }^{b}$, Angélica \\ Guadalupe Hernández Zanabria ${ }^{b}$
}

\begin{abstract}
:
On new global energetic paradigm, they are growing new methods, techniques and technologies to generate clean energy, however, those methods, techniques and technologies, are affected by different circumstance and variables. Solar energy generation field has also different circumstances that affect its efficiency. The aim of this research is to point out those different factors which can affect solar energy generation, taking particular interest on a photovoltaic system when they appear snail traces (micro-crackings) in the photovoltaic module (PV-module), particularly when there exists client's claim because of that situation.
\end{abstract}

Keywords:

Microcracking, PV-system, Snail trace, Snail trail

\section{Resumen:}

El nuevo paradigma energético permite el surgimiento de nuevos métodos, técnicas y tecnologías para generación de energías verdes, sin embargo, estos métodos, técnicas y tecnologías se ven afectados por diferentes factores y variables. El campo de generación de energía solar se ve afectado por circunstancias que merman su eficiencia. El presente documento tiene por objeto presentar los factores que merman la generación de energía, tomado especial atención, en la aparición de microfracturas también conocidas como sendas de caracol, para los sistemas fotovoltaicos, lo cual puede hacer surgir quejas y reclamos por parte de los clientes de este tipo de sistemas de generación de energía.

\section{Palabras Clave:}

Microfracturas, Módulos fotovoltaicos, Sendas de caracol

\section{Introducción}

Actual world wide spread worrying for environmental care is emerging not only in developed countries but also in those developing countries. That is the reason because of which, renewable energies are having a wide spread. Governments have also a great interest on that topic and they are investing huge resources to change, for example, its electricity traditional production methods to renewable ones. In the particular scope of electricity generation there exist methods of production whit renewable energy like, wind, geothermal, solar, among others production methods.

Solar energy is wide used in our day by day context. Basically, there exist two kinds of usage of solar energy, photothermal and photovoltaic. In one hand, as mentioned in [1], photothermal conversion of solar energy into work is sometimes referred to as an indirect conversion, i.e., conversion of solar energy into heat by collection in the solar absorber and subsequent conversion of this heat into work by means of Carnot engine. In another hand, photovoltaic conversion of 
solar energy is a direct process in which, solar energy is used to generate direct current.

\section{Theoretical background}

Solar cell is a two-semiconductor junction. Inside of the PV-module or solar panel, each solar cell holds a minimum power difference (voltage) of $0.5 \mathrm{~V}$ to $0.6 \mathrm{~V}$, which helps the two semiconductors to stay together. That means that a panel of 230W, 245W, 250W, 255W, $260 \mathrm{~W}, 265 \mathrm{~W}$ and in general those PV-modules of $164 \mathrm{~mm}^{*} 990 \mathrm{~mm}$, composed by 60 solar cells, can be measured from $30 \mathrm{~V}$ to $36 \mathrm{~V}$ in an operative circuit. As solar cells would be connected in series, the current hold by the PV-module is $8 \mathrm{~A}$, with solar cells of $156 \mathrm{~mm}^{*} 156 \mathrm{~mm}$.

A literature review made by Jordan \& Kurtz in 2012 [2], in which it is analyzed a 40 -year period of photovoltaic system, was founded that degradation rate is $0.5 \%$ per year, at same time, they found that median degradation between: 0 and 10 years is $0.70 \%$ per year; 10 and 20 years is $0.46 \%$ per year; and, over 20 years is $0.43 \%$ per year (Fig. 1).

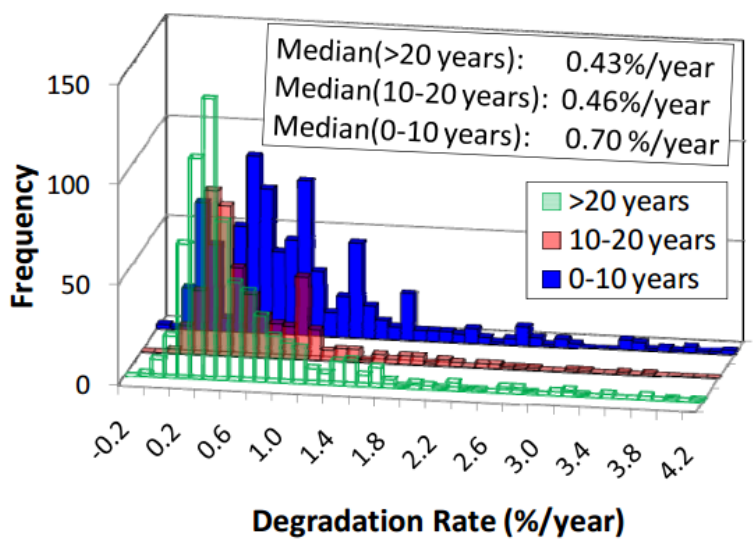

Fig. 1: Degradation rate histogram grouped by outdoor exposure length. The median rate for exposure length up to 10 years is significantly higher than for studies of 10 years and longer. Source: Jordan \& Kurtz (2012) [2]

Different factors affect or reduce energy production in a photovoltaic. Some factors that can reduce a PV module efficiency are, for example: wrong installation (wires, protections, inclination, orientation, etc.), manufacture defects, wrong transportation, wrong warehousing, installation of different power PV modules (e.g. $150 \mathrm{~W}$ with $265 \mathrm{~W}$ or $265 \mathrm{~W}$ with 310 ), dust or garbage over the PV modules, presence of shadows over PV modules along the day, among others, that can be solved by fixing the installation, cleaning, reorienting or replacing any subsystem or part of the PV system. In the case of in situ installation, it is recognized that PV module typically offers just around the $80 \%$ of its nominal power, reduction on the power due to that distinctive effect can be calculated as follows (Eq. 1):effective power in situ $=$ $($ nominal power $* 80) / 100 \ldots$. .

There exists a problem that affect photovoltaic systems and cannot be solved (without panel replacement or installation fixing), neither by the installer nor an external agent nor the client, which is called snail trace problem.

A snail trace also called snail trail, as indicated by the name, is a kind of mark or stain which is very similar to the way that a snail left behind when it moves. Snail traces are mainly produced by micro-cracking in the solar cell. Typical dark traces called "snail trails" are always located at the cell edge or along micro cracks which can be easily detected by EL (electroluminescence) [3] (Fig. 2).

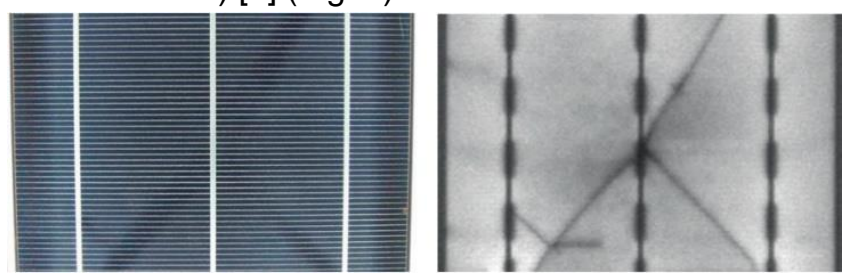

Fig. 2: Visual appearance of snail trails at cell edges and along micro cracks (left), EL image of the same cell piece to indicate the micro crack positions (right). Source: Meyer et al. (2013) [3]

It is possible to state, based on experience, that relation between efficiency lost and breakage area's percentage is approximately $0.20 \%$, which means that if we have a solar cell breakage of $5.35 \%$, efficiency lost can be $5.15 \%(5.35 \%-0.20 \%)$. In that sense, it can be state, that to have a considerable efficiency lost, it is needed to have a more that $20 \%$ breakage on the whole PV-module. That because, solar cell structure makes it likely to collect as much energy as possible, thorough the primary and secondary busses or collectors (Fig. 3). 


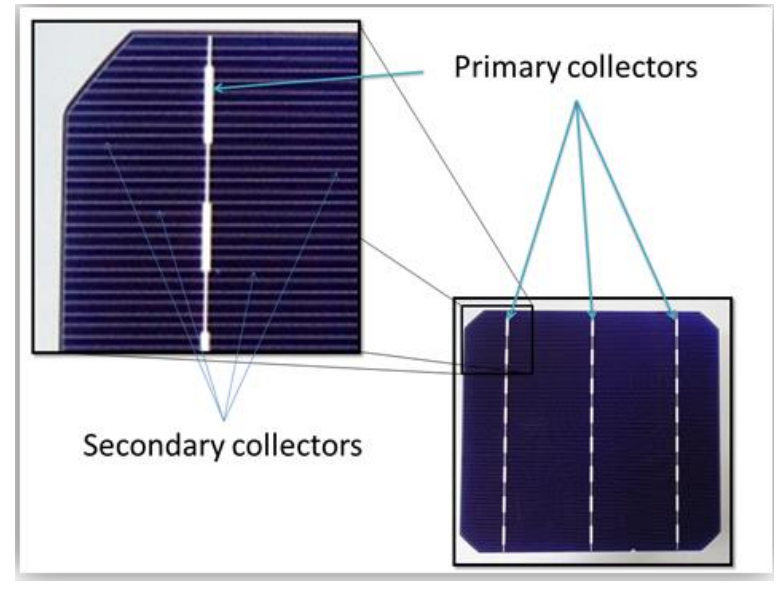

Fig. 3: Primary and secondary collectors or busses in a mono-crystalline solar cell. Source: Self-designed

Generally, snail traces appear after manufacturing process, when the panel are transported or installed, mainly because the panel is loaded with a continuous pressure over it surface or because it is transported in a very irregular route (suffering to many vibrations). It is necessary to consider that, despite PV-modules are designed to hold very unpropitious (hard) environments; it is good to care about them, even in the transportation or installation.

In the practice, given power (W) by a PV module, can be calculated based on two variables that can be measured in situ, voltage and current. That calculation can be done as follows (Eq. 2):

where:

$$
\operatorname{Power}_{W}=(V * I) \ldots . .
$$

Power $_{W}$ Power of a PV modules measured

$V \quad$ Voltage measured in volts

I Current measured in ampers

Once they are obtained the measurements in situ, it can be calculated the power of a PV module, with those two data. Most of the cases, a PV system have more than two PV modules, which makes important to determine the average power of the PV system in the mentioned case. Average power can be calculated as follows (Eq. 3):

where:

$$
\overline{\text { Power }_{W}}=\sum_{i=1}^{n}\left(V_{i} * I_{i}\right) / n \ldots
$$

$$
\begin{array}{cc} 
& \overline{P o w e r}_{W} \quad \begin{array}{c}
\text { Average power of PV system } \\
\text { measured in watts }
\end{array} \\
V_{i} & \text { Voltage of the i-PV module } \\
I_{i} & \text { Current of the i-PV module measured in volts } \\
n & \text { Total number of PV modules in }
\end{array}
$$$$
\text { the PV system }
$$

They also can be calculated the average voltage and average current, as follows (Eq. 4, Eq. 5):

$$
\bar{V}=\sum_{i=1}^{n} V_{i} / n \ldots
$$

where:

$\bar{V} \quad$ Average voltage of $P V$ system

$V_{i} \quad$ Voltage of the i-PV module measured in volts

$n$ measured in volts Total number of PV modules in the

PV system

$$
\bar{I}=\sum_{i=1}^{n} I_{i} / n \ldots
$$

where:

I $\quad$ Average voltage of PV system

$I_{i} \quad$ Current of the i-PV module measured in amperes $n$ measured in amperes Total number of PV modules in

the PV system

\section{Solar system under study}

Tested photovoltaic system is located in Morelos' state, in the municipality of Yautepec at 18.861 latitude and -99.061 longitude. Yautepec's surface parameter are: $1535 \mathrm{~m}$ of elevation, $103.78^{\circ} \mathrm{C}$ of heating design temperature, $27.61^{\circ} \mathrm{C}$ of cooling design temperature, $15.48{ }^{\circ} \mathrm{C}$ of earth temperature amplitude and 0 (cero) frost days at site.

The system was integrated by 15 solar panels of 245 W. Those panels were bought on April 22 ${ }^{\text {nd }}, 2013$, which serial numbers are: 50143, 50162, 50166, 50174, 50188, 50189, 50190, 50192, 50213, 50220, $50223,50224,50243,50250$ and 50253 , the snail trails or snail traces detected in the panel are like shown in Fig. 4, Fig. 5 and Fig. 6.

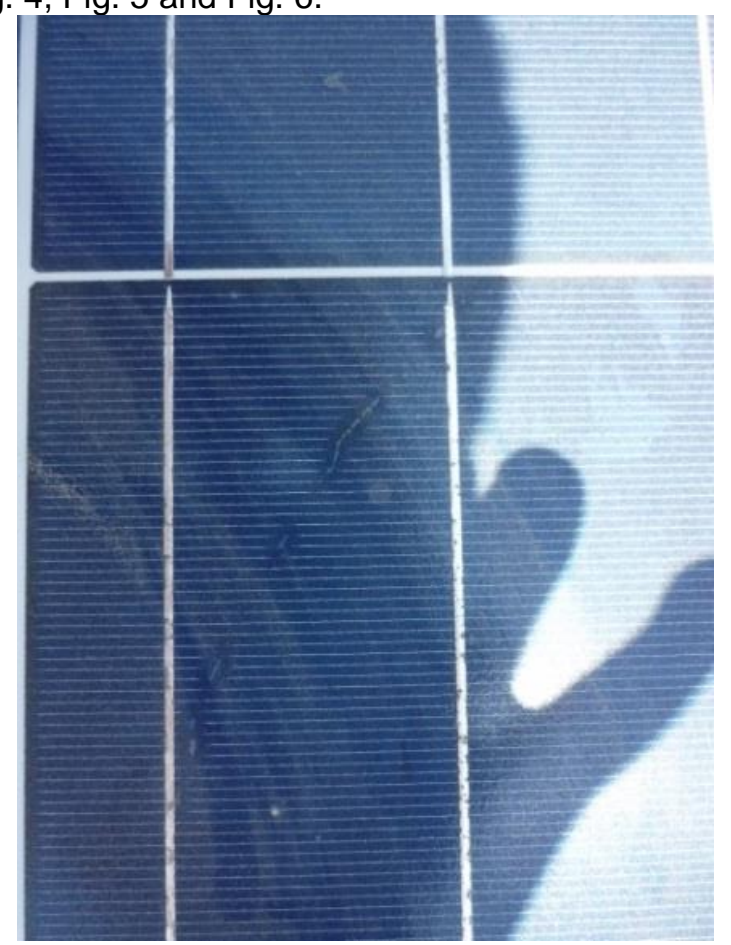

Fig. 4: Snail trail founded in the PV-system (a). Source: sent by the installer, taken in situ 


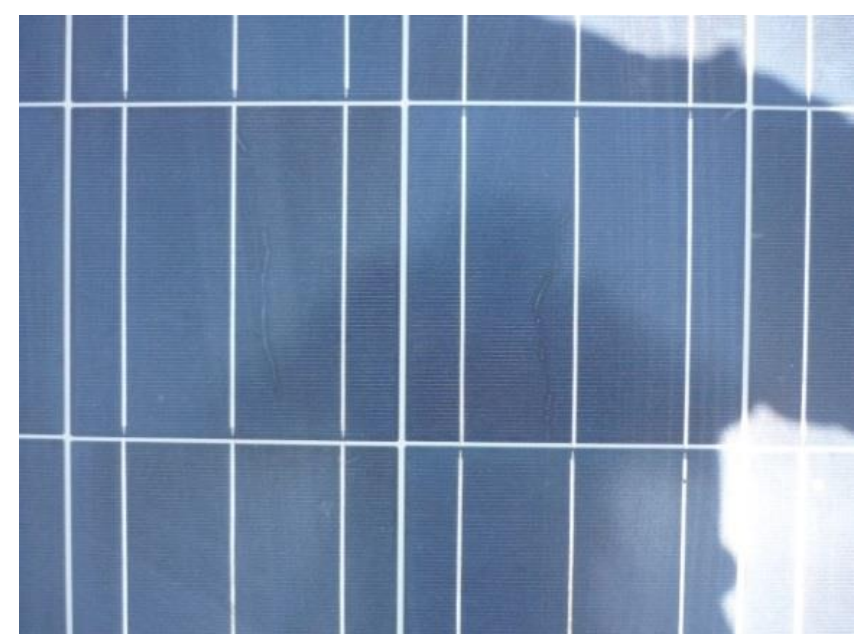

Fig. 5: Snail trail founded in the PV-system (b). Source: sent by the installer, taken in situ

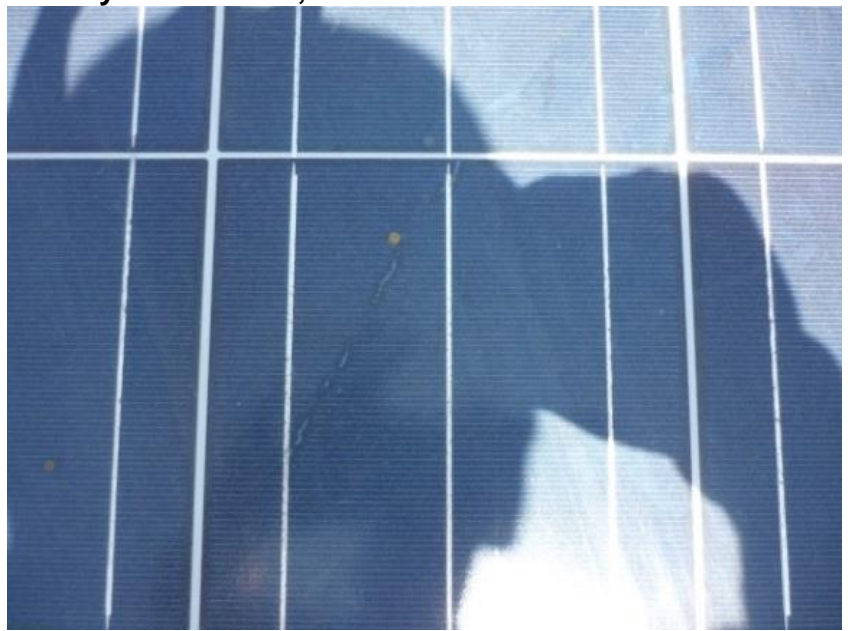

Fig. 6: Snail trail founded in the PV-system (c). Source: Pictures taken in situ

The minimum voltage of a $245 \mathrm{~W}$ panel must be at least $30 \mathrm{~V}$ and current should be at least $8 \mathrm{~A}$. When they were measured the 15 PV-modules of $245 \mathrm{~W}$, there were founded the following measurements (Table 1). They are highlight in red, those measurements which are not close to a standard parameter.
TABLE I

MEASURES COLLECTED IN SITU

\begin{tabular}{cccc}
\hline \hline$\#$ & Serial number & Voc [V] & Ioc [A] \\
\hline 1 & 50143 & 34.01 & 8.50 \\
2 & 50162 & 33.24 & 6.30 \\
3 & 50166 & 33.12 & 8.70 \\
4 & 50174 & 32.88 & 9.00 \\
5 & 50188 & 33.14 & 8.40 \\
6 & 50189 & 33.37 & 8.30 \\
7 & 50190 & 33.02 & 8.80 \\
8 & 50192 & 33.50 & 8.40 \\
9 & 50213 & 33.23 & 6.20 \\
10 & 50220 & 33.10 & 6.20 \\
11 & 50223 & 33.04 & 7.80 \\
12 & 50224 & 33.28 & 8.40 \\
13 & 50243 & 33.31 & 6.30 \\
14 & 50250 & 33.65 & 8.20 \\
15 & 50253 & 33.03 & 6.10 \\
\hline \hline
\end{tabular}

Voc measured in Volts [V], Ioc measured in Amperes [A] Average voltage for 15 panels is $33.26 \mathrm{~V}$

Average current for 15 panels is $7.71 \mathrm{~A}$

To view direct measures, you can check Annex I.

In the following table it can be seen taken measurement and calculation of each PV module theoretical power. Power in each case was calculated with (Eq. 2), and the $256.38 \mathrm{~W}$ theoretical power average by PV system was calculated with (Eq. 3).

TABLE I

MEASURES COLLECTED IN SITU

\begin{tabular}{ccccc}
\hline \hline$\#$ & $\begin{array}{c}\text { Serial } \\
\text { number }\end{array}$ & Voc [V] & Ioc [A] & Power [W] \\
\hline 1 & 50143 & 34.01 & 8.50 & 289.09 \\
2 & 50162 & 33.24 & 6.30 & 209.41 \\
3 & 50166 & 33.12 & 8.70 & 288.14 \\
4 & 50174 & 32.88 & 9.00 & 295.92 \\
5 & 50188 & 33.14 & 8.40 & 278.38 \\
6 & 50189 & 33.37 & 8.30 & 276.97 \\
7 & 50190 & 33.02 & 8.80 & 290.58 \\
8 & 50192 & 33.50 & 8.40 & 281.40 \\
9 & 50213 & 33.23 & 6.20 & 206.03 \\
10 & 50220 & 33.10 & 6.20 & 205.22 \\
11 & 50223 & 33.04 & 7.80 & 257.71 \\
12 & 50224 & 33.28 & 8.40 & 279.55 \\
13 & 50243 & 33.31 & 6.30 & 209.85 \\
14 & 50250 & 33.65 & 8.20 & 275.93 \\
15 & 50253 & 33.03 & 6.10 & 201.48 \\
\hline \hline
\end{tabular}

Voc measured in Volts [V], Ioc measured in Amperes [A], Power measured in Watts [W]

Average voltage for 15 panels is $33.26 \mathrm{~V}$

Average current for 15 panels is $7.71 \mathrm{~A}$

Average power for 15 panels is $33.03 \mathrm{~W}$

To view direct measures, you can check Annex I. 


\section{Conclusion}

Typically, voltage in 60 solar cell PV-modules must to be at minimum $30 \mathrm{~V}$, based on the on it, it is possible to state, that solar panels installed in Yautepec, Morelos, Mexico, have an excellent performance, despite the snail trails that have already appear on the PV-system. On that matter, it is recommendable that systems with snail trails have a monitoring process, in which it can be compared the production of energy, between different periods (for example in 2014 and 2015, 2015 and 2016, and, 2016 and 2017). Focusing on principal aim of a photovoltaic system, "energy generation", when it decreases more than normal, it is a symptom of a real problem in the PV-system, otherwise, minor problems can be hold without affecting the energy production.

\section{Acknowledgment}

The authors want to thank client who provide access to take measures of photovoltaic system. Authors also thank Solarever Tecnología de América, photovoltaics' enterprise, which give the support to understand the assemble process of photovoltaic modules. Non-less important, authors what to thank Autonomous University of Hidalgo (Universidad Autónoma del Estado de Hidalgo - UAEH) by its support on knowledge providing.

\section{References}

[1] de Vos, A. (2008). Thermodynamics of solar energy conversion, Chapter 6: Photovoltaic conversion, Wiley-VCH Verlag Gmbh \& Co. KGaA, Weinheim, Germany, ISBN 978-3-527-40841-2.

[2] Jordan, D.C. \& Kurtz, S.R. (2012). Photovoltaic Degradation Rates An Analytical Review, Progress in Photovoltaics: Research and Applications, National Renewable Energy Laboratory (NREL), Alliance for Sustainable Energy, U.S. Department of Energy, Office of Energy Efficiency \& Renewable Energy, available at: [http://www.nrel.gov/docs/fy12osti/51664.pdf].

[3] Meyer, S., Richter, S., Timmel, S., Gläser, M., Werner, M. Swateka, S \& Hagendorf, C. (2013). Snail trails: root cause analysis and test procedures, Energy Procedia 38, pp. 498 - 505, 1876-6102 @ 2013 The Authors. Published by Elsevier Ltd., Selection and/or peer-review under responsibility of the scientific committee of the SiliconPV 2013 conference, doi: 10.1016/j.egypro.2013.07.309, SiliconPV: March 2527, 2013, Hamelin, Germany, available at:

[http://www.sciencedirect.com/science/article/pii/S1876610213013957 ]. 